\title{
Chapter 2 \\ Revisiting Intangible Capital and Labor \\ Productivity Growth, 2000-2015: \\ Accounting for the Crisis and Economic \\ Recovery in the EU
}

\author{
Felix Roth
}

\begin{abstract}
Purpose-This contribution aims to revisit the relationship between intangible capital and labor productivity growth using the largest, up-to-date macro database (2000-2015) available to corroborate the econometric findings of earlier work and to generate novel econometric evidence by accounting for times of crisis (2008-2013) and economic recovery (2014-2015).

Design/methodology/approach-To achieve these aims, the study employs a cross-country growth-accounting econometric estimation approach using the largest, up-to-date database available encompassing 16 EU countries over the period 2000-2015. It accounts for times of crisis (2008-2013) and of economic recovery (2014-2015). It separately estimates the contribution of three distinct dimensions of intangible capital: 1) computerized information, 2) innovative property, and 3) economic competencies.
\end{abstract}

Originally published in: Felix Roth. Revisiting Intangible Capital and Labour Productivity Growth, 2000-2015: Accounting for the crisis and economic recovery in the EU. Journal of Intellectual Capital, Vol. 21, No. 5, 2020, pp. 671-690.

The author wishes to thank the participants at the 15th World Conference on Intellectual Capital for Communities in Paris (July 2019), the GLOBALINTO meeting in Athens (September 2019) and the GLOBALINTO workshop on Advancing the Measurement of Intangibles for European economies in Brussels (January 2020) for constructive comments. He would also like to thank Simone Calió for excellent research assistance. Moreover, Dr. Roth is grateful for a grant received from the European Commission under the Horizon 2020 programme for the GLOBALINTO project (Capturing the value of intangible assets in microdata to promote the EU's growth and competitiveness, contract number 822259). And finally, he expresses his gratitude to Ahmed Bounfour, Hannu Piekkola, Felicitas Nowak-Lehmann, Thomas Straubhaar, Iulia Siedschlag, Robert Stehrer and Josh Martin for their valuable comments.

Felix Roth $(\bowtie)$

Department of Economics, University of Hamburg, Hamburg, Germany

e-mail: felix.roth@uni-hamburg.de

F. Roth, Intangible Capital and Growth, Contributions to Economics, https://doi.org/10.1007/978-3-030-86186-5_2 
Findings-First, when accounting for intangibles, this contribution finds that these intangibles have become the dominant source of labor productivity growth in the EU, explaining up to $66 \%$ of growth. Second, when accounting for times of crisis (2008-2013), in contrast to tangible capital, it detects a solid positive relationship between intangibles and labor productivity growth. Third, when accounting for the economic recovery (2014-2015), it finds a highly significant and remarkably strong relationship between intangible capital and labor productivity growth.

Originality/value - The study corroborates the importance of intangibles for labor productivity growth and thereby underlines the necessity to incorporate intangibles into today's national accounting frameworks in order to correctly depict the levels of capital investment being made in European economies. These levels are significantly higher than those currently reflected in the official statistics.

Keywords Intangible capital - Labor productivity growth · Crisis · Recovery · European Union

\section{Introduction}

Recent research has reported a disappointing performance in labor productivity growth among European Union (EU) and euro area (EA) countries since the start of the crisis from 2008 to 2015 (Van Ark \& Jäger, 2017). According to this literature, this performance stems largely from a slower diffusion of technology and innovation due to low growth rates of information and communication technology (ICT) and complementary intangible capital investment (Van Ark \& Jäger, 2017, p. 15; Van Ark, 2016, pp. 37-41; Van Ark \& O’Mahony, 2016, pp. 132-138).

Indeed, a recent growth-accounting study at the macro-level over the period 2000-2013 identifies the deepening of intangible capital as a main driver of labor productivity growth (Corrado et al., 2018, p. 11). Such findings are in line with existing growth-accounting studies for the US (Corrado et al., 2009), the UK (Marrano et al., 2009), Japan (Fukao et al., 2009), Sweden (Edquist, 2011), and the EU-15 (Corrado et al., 2013).

Within this substantial body of growth-accounting evidence, however, there exists only scarce econometric evidence at the macro-level of the impact of intangible capital investment on labor productivity growth. The only existing econometric study analyses an EU-13 country sample for pre-crisis times from 1998 to 2005 (Roth \& Thum, 2013). This scarcity of growth econometric studies is remarkable in light of their general advantages in comparison to growth-accounting studies (Temple, 1999, pp. 120-121). To help close this gap in the research, this study conducts an econometric analysis using a cross-country growth-accounting approach covering 16 EU countries over the period 2000-2015. This approach goes beyond earlier 
work in two ways. First, it enables us to corroborate earlier econometric findings (Roth \& Thum, 2013) with the help of a greatly extended dataset containing more than two and half times the number of overall observations (256 versus 98 ). Second, by covering a period until 2015 , we are able to generate novel econometric findings on the impact of intangible capital deepening on labor productivity growth by accounting for times of crisis (2008-2013) and times of economic recovery (2014-2015).

By matching the most recent release of the INTAN-Invest (NACE2) ${ }^{1}$ dataset (Corrado et al., 2018) with the latest figures from the EU KLEMS ${ }^{2}$ dataset (Jäger, 2017), in combination with a wide range of growth-relevant policy variables from Eurostat, the OECD and the World Bank, this contribution provides the largest upto-date intangible capital panel dataset at the macro-level containing an overall number of 256 country observations. Estimating a slightly modified model specification as developed within the existing literature (Roth \& Thum, 2013, p. 495), with the help of a cross-country growth-accounting econometric approach, this contribution reaches three major findings. First, in line with the previous growth econometric literature (Roth \& Thum, 2013), it confirms that once intangibles are accounted for, they become the dominant source of labor productivity growth in the EU, explaining up to $66 \%$ of this growth. Second, when accounting for times of crisis (2008-2013), it finds that even when the relationship between tangible capital and labor productivity turned negative, the impact of intangibles on growth remained solidly positive. Third, when accounting for the economic recovery (2014-2015), it reports a highly significant and remarkably strong relationship between intangible capital and labor productivity growth.

\section{Theoretical Linkages between Intangible Capital and Labor Productivity Growth}

The earliest work highlighting the importance of intangible capital for labor productivity dates back to the 1960s (Haskel \& Westlake, 2018, p. 38). Based on research by Brynjolfsson et al. (2002) and Nakamura (2001), among others, Corrado et al. (2005) developed a methodological framework for the US of how to account for business intangibles in the "new economy". The authors used an intertemporal framework for investment and grouped the various business intangibles into three broad dimensions: 1) computerized information, namely software, 2) innovative property, namely research \& development $(\mathrm{R} \& \mathrm{D})$ and 3) economic competencies, namely brand names, firm-specific human capital and organizational capital. Conducting a growth-accounting analysis alongside their methodological framework, Corrado et al. (2009) showed that business intangibles were able to explain

\footnotetext{
${ }^{1}$ Accessible at www.intaninvest.net (Corrado et al., 2018).

${ }^{2}$ Accessible at www.euklems.net (Jäger, 2017).
} 
a significant share of labor productivity growth. Using growth-accounting studies, similar results were found for the UK (Marrano et al., 2009), Japan (Fukao et al., 2009), Sweden (Edquist, 2011) and the EU (Corrado et al., 2013, 2018). Econometric cross-country growth-accounting studies for the EU (Roth \& Thum, 2013) find an even stronger impact of intangibles on labor productivity growth. In addition, the positive relationship between intangible capital and labor productivity was prominently discussed and established in the work of Bounfour (Bounfour \& Miyagawa, 2015; Delbecque et al., 2015); Piekkola (2016, 2018) and Miyagawa (Miyagawa \& Hisa, 2013; Bounfour \& Miyagawa, 2015).

The positive relationship between computerized information and labor productivity growth-particularly the interaction between software and organizational capital (Brynjolfsson et al., 2002) — and R\&D and labor productivity growth (Guellec \& van Pottelsberghe de la Potterie, 2001) has already been well established in the literature. Consequently, the intangible assets-software, R\&D and entertainment, artistic and literary originals, and mineral exploration - were already included in the asset boundary of the national accounts. Given that economic competencies, in particular, were not yet included in the national accounts, it seems necessary to once more elaborate their positive role in labor productivity growth. Concerning brand names, Cañibano et al. (2000) argue that the ownership of an attractive brand permits a seller to retain a higher margin for goods or services compared to his competitors. Since the consumer is driven by his perceptions in choosing among the products of competing firms, the development of an appealing image or brand is crucial in producing future benefits. Concerning training or firm-specific human capital, the same authors stress that a firm with higher-skilled employees is likely to attain higher profits than competitors whose workers are less competent. This observation is in line with Abowd et al. (2005), who argue that the value of a firm will increase if the quality of its firm-specific human capital resources improves. Concerning organizational capital, Lev and Radhakrishnan (2005, p. 75) define organizational capital as "an agglomeration of technologies (...) business practices, processes and designs and incentive and compensation systems-that together enable some firms to consistently and efficiently extract from a given level of physical and human resources a higher value of product than other firms find possible to attain.” The authors classify this as the only competitive asset truly possessed by a firm, whereas the others are exchangeable and thus can be obtained by any company prepared to make the necessary investment.

\section{Estimates on Intangible Capital}

A methodological framework originally developed by Corrado et al. (2005) for measuring business intangibles in the US has become widely used internationally. The framework was adopted in individual country-case studies for the UK (Marrano 
et al., 2009), Japan (Fukao et al., 2009), and Sweden (Edquist, 2011). Adapting this methodological framework to the EU, the FP7 INNODRIVE project ${ }^{3}$ constructed the first harmonized dataset for an EU-27 country sample (plus Norway), alongside the three dimensions mentioned above. It contained two "old" national account intangibles and eight "new" intangibles over the time period 1980-2005 (INNODRIVE, 2011; Jona-Lasinio et al., 2011; Gros \& Roth, 2012; Roth \& Thum, 2013). The INNODRIVE macro database was used as the base for the EU-27 countries within the first version of the INTAN-Invest (NACE1) datase ${ }^{4}$ - a harmonized and updated intangible dataset covering the EU and the US over the time period 1980-2010 (Corrado et al., 2013). In developing the second version of the INTAN-Invest (NACE2) dataset, Corrado et al. $(2016,2018)$ significantly altered their methodology to provide information on intangible capital on single-digit NACE2 economic sectors and updated their dataset in the latest January 2019 release until the year 2015.

The INTAN-Invest (NACE2) covers 19 EU countries plus the US over the period 1995-2015. The dataset measures three "old" national account intangibles and five "new" intangibles. The dataset groups business intangibles under three dimensions: 1) computerized information, 2) innovative property and 3) economic competencies. The first dimension, i.e. computerized information, contains computer software and databases. The second dimension, i.e. innovative property, contains 1) entertainment, artistic and literary originals, and mineral exploration, 2) $R \& D, 3$ ) design and 4) new product development in the financial industry. The third dimension, i.e. economic competencies, contains 1) brand, 2) firm-specific human capital and 3) organizational capital. A detailed explanation of the altered methodology of the INTAN-Invest (NACE2) dataset is provided in Corrado et al. (2016), pp. 42-47.

\section{Previous Empirical Results}

Table 2.1 gives an overview of the existing empirical results of the growthaccounting and cross-country growth econometric literature analyzing the relationship between business intangible capital and labor productivity growth by businesses at the macro-level. The table displays three distinct effects once intangible capital has been incorporated into the asset boundary of the national accounts.

In the first instance, the table clarifies that investments in intangible capital reach significant levels, once they are fully accounted for. Analyzing the business investment level for the US in pre-crisis times, Corrado et al. (2009) find a business investment level of 13\% of non-farm business output, whereas Nakamura (2010) finds equal shares of intangible and tangible capital investments. Similar investment

\footnotetext{
${ }^{3}$ Accessible at https://cordis.europa.eu/project/id/214576/reporting/de (INNODRIVE, 2011).

${ }^{4}$ Accessible at www.intaninvest.net (Corrado et al., 2013).
} 


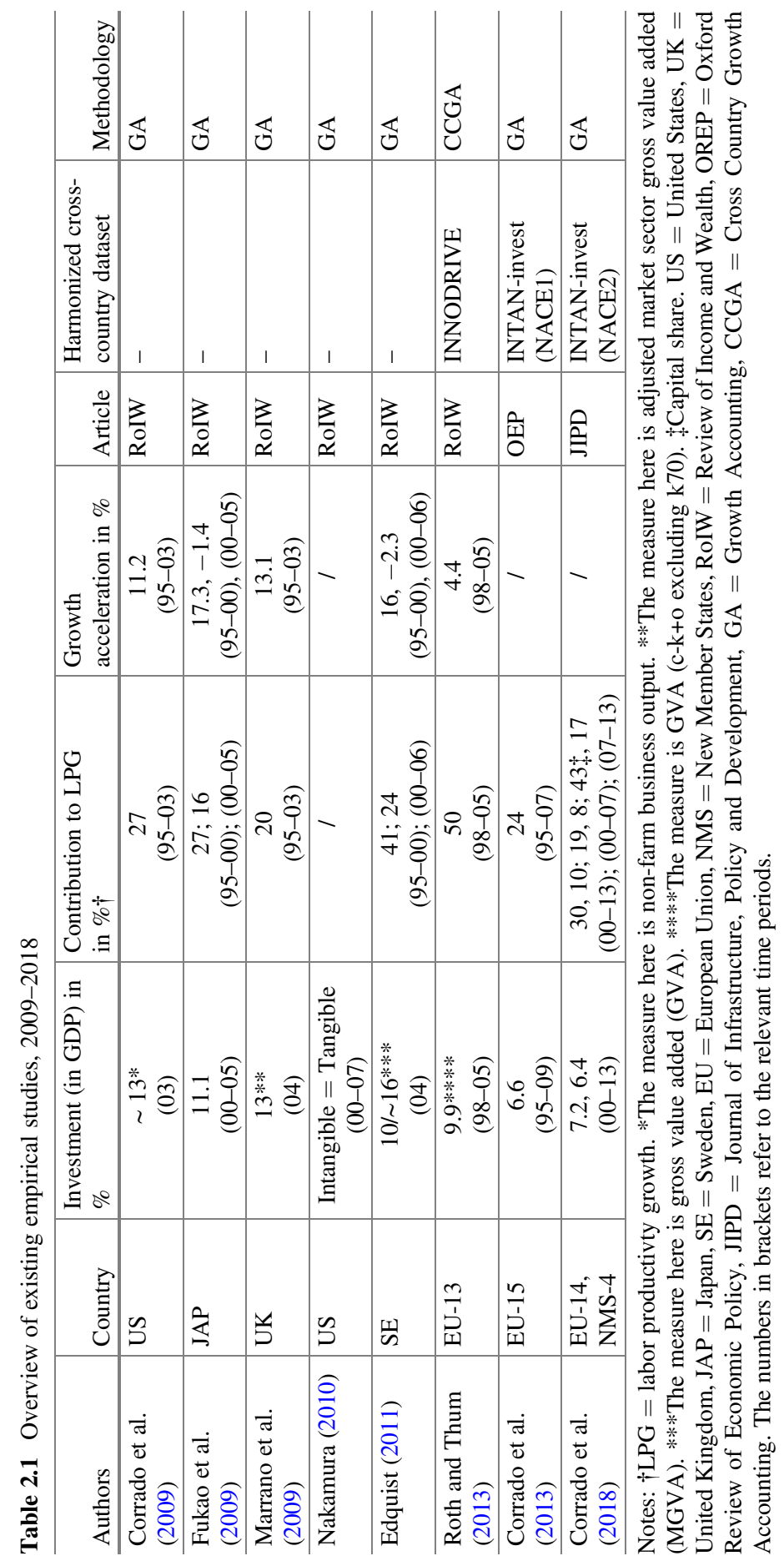


rates for precrisis times are found for Japan (Fukao et al., 2009) and the UK (Marrano et al., 2009) with $11.1 \%$ of GDP and $13 \%$ of adjusted MGVA (market sector gross value added), respectively. With a value of $16 \%$ of GVA(gross value added), higher business investment rates are found in Sweden (Edquist, 2011). Utilizing INNODRIVE data, Roth and Thum (2013) find an average business investment rate for precrisis times (1998-2005) for 13 EU countries of $9.9 \%$ of GVA. Utilizing the first version (NACE1) of the INTAN-Invest dataset, Corrado et al. (2013) find an average business investment rate of 6.6\% of GDP for an EU-15 country sample from 1995 to 2009. Utilizing the second version of the INTANInvest (NACE Rev.2) dataset, Corrado et al. (2018) find an average investment rate for business intangibles for the EU-14 and NMS-4 of $7.2 \%$ and $6.4 \%$ of GDP, respectively, from 2000 to 2013.

Second, the contribution from intangible capital services to labor productivity growth is significant. Once business intangible capital is accounted for, $27 \%$ and $20 \%$ of labor productivity growth were explained in the US and the UK, respectively. The same and higher values of up to $41 \%$ hold for Japan and Sweden (Fukao et al., 2009; Edquist, 2011). Utilizing INNODRIVE data and analyzing 13 EU countries with the help of an econometric cross-country growth-accounting methodological approach, Roth and Thum (2013) find that 50\% of labor productivity can be explained. Using INTAN-Invest (NACE1) data for an EU-15 country sample over the time period 1995-2009, Corrado et al. (2013) find a value of 24\%. In their most recent study, using INTAN-Invest data (NACE2), Corrado et al. (2018) differentiate between a precrisis and a crisis period. They find that intangible capital contributes $30 \%$ over the time period $2000-2013$, and $19 \%$ and $43 \%$ in times of precrisis and crisis respectively, for an EU-14 country sample.

Third, the capitalization of intangibles accelerates productivity growth.

\section{Model Specification, Research Design and Data}

\subsection{Model Specification}

We estimate a slightly revised model specification as developed in the existing econometric literature (Roth \& Thum, 2013, p. 495). Following this literature, the slightly revised model specification takes the following form:

$$
\begin{aligned}
\left(\ln q_{i, t}-\ln q_{i, t-1}\right)= & c+g H_{i, t}+m H_{i, t} \frac{\left(q_{\max , t}-q_{i, t}\right)}{q_{i, t}}+n\left(1-u r_{i, t}\right) \\
& +p \sum_{j=1}^{k} X_{j, i, t}+y d_{i, t}+\alpha\left(\ln k_{i, t}-\ln k_{i, t-1}\right) \\
& +\beta\left(\ln r_{i, t}-\ln r_{i, t-1}\right)+u_{i, t}
\end{aligned}
$$


where $\left(\ln q_{i, t}-\ln q_{i, t-1}\right)$ is labor productivity growth (GVA expanded by intangibles and divided by total hours worked) for the non-farm business sectors $b-n+r-s$ excluding real estate activities expanded by the investment flows of business intangible capital in country $i$ and period $t$. The constant term $c$ represents exogenous technological progress; the level of human capital $\left(H_{i, t}\right)$ reflects the capacity of a country to innovate domestically; and the term $H_{i, t}\left(q_{\max , t}-q_{i, t}\right) / q_{i, t}$ proxies a catchup process, with $q_{\text {max, } t}$ using a purchasing power parity-weighted GVA measure divided by total hours worked and representing the country with the highest level of labor productivity at period $t$. The term $\left(1-u r_{i, t}\right)$ takes into account the business cycle effect proxied by 1 minus the unemployment rate $(u r)$; the term $\sum_{j=1}^{k} X_{j, i, t}$ is the sum of $k$ extra policy variables, which could possibly explain TFP (total factor productivity) growth and $y d_{i, t}$ are year dummies to control among others for the economic downturn in 2001, in the wake of the bursting of the information technology bubble in the previous year and the 9/11 attack in 2001, as well as the pronounced economic downturn since 2008. $\left(\ln k_{i, t}-\ln k_{i, t-1}\right)$ and $\left(\ln r_{i, t}-\ln r_{i, t-1}\right)$ represent the growth of tangible and intangible capital services, and $u_{i, t}$ represents the error term.

\subsection{Research Design}

The econometric analysis covers 16 out of $27 \mathrm{EU}$ countries from 2000 to 2015. The countries included are Austria, Czech Republic, Denmark, Finland, France, Germany, Greece, Ireland, Italy, the Netherlands, Portugal, Spain, Slovakia, Slovenia, Sweden, and the United Kingdom. ${ }^{5}$ With 16 EU countries and 16 time periods from 2000 to 2015, this leaves the econometric analysis with an overall number of 256 observations. Following the approach by Roth and Thum (2013, p. 496), annual growth rates from 2000 to 2015 were estimated. The econometric analysis was restricted to a period of 2000-2015, due to the valid calculation of capital stock data. Equation (2.1) is estimated with the help of an econometric cross-country growth accounting approach. This approach differs from traditional single-growth accounting in two ways. First, the output elasticities are estimated rather than imposed. And second, the model can be designed to explain the international variance in TFP (total factor productivity) growth. The whole research design applies to non-farm business sectors $b-n+r-s$ excluding real estate activities. For Greece, Ireland, and Portugal, measures for the total economy were adjusted to the non-farm business sectors. For Greece, disproportionately high levels of organizational capital investment were adjusted to an average EU-16 level. Measurement errors and missing values in the latest releases of the EU KLEMS (Jäger, 2017) and

\footnotetext{
${ }^{5}$ The cases for Belgium and Hungary were excluded due to missing data in the EU KLEMS dataset. Luxembourg was excluded due to significant inconsistencies in the intangible capital data.
} 
the INTAN-Invest (NACE2) dataset (Corrado et al., 2018) were dealt with when necessary. ${ }^{6}$

\subsection{Data Sources}

The data were retrieved from the sources specified below:

1. Data on the single components of intangible capital were taken from the INTANInvest (NACE2) dataset (Corrado et al., 2018), which provides information on gross fixed capital formation (GFCF) and intangibles adjusted GVA. The data cover 19 EU countries + the US over the period 1995-2015, for 21 NACE2 economic sectors. The INTAN-Invest (NACE2) dataset does not provide intangible capital stocks.

2. Data on the single components of tangible capital were taken from the EU KLEMS database (Jäger, 2017). The database provides data on GFCF, tangible capital stocks, GVA, labor compensation, capital compensation, and number of hours worked per employee. The data cover the EU-28 countries and the US, over the period 1995-2015, for 21 NACE2 economic sectors.

3. Human capital is measured as the percentage of the population aged $15+$ that has attained at least upper-secondary education, which is taken as a proxy for the stock of human capital. The data were obtained from Eurostat.

4. Data on unemployment, power purchasing parity (PPP), inflation (HICP), government expenditures on education (percent of GDP), total government expenditures (percent of GDP), social expenditure (percent of GDP), and stock of foreign direct investment (FDI) (percent of GDP) were obtained from Eurostat.

5. Data on income tax (as a percent of GDP) were obtained from the OECD. The variables rule of law (Kaufmann et al., 2010), data on market capitalization (percent of GDP), and openness to trade were retrieved from the World Bank.

\subsection{A Note on the Construction of Intangible Capital Stocks}

In line with the literature (Niebel et al., 2017, p. 55; Roth \& Thum, 2013, p. 497; Timmer et al., 2007, pp. 32 and 39), intangible capital stocks for the selected 16 EU-27 countries for the time period 2000-2015 were constructed by applying the perpetual inventory method (PIM) to a series of intangible capital investment going back to 1995 and using the depreciation rates $\left(\delta_{R}\right)$ as suggested by Corrado et al. (2009): $20 \%$ for R\&D, design, and new product development in the financial services industry; $35 \%$ for software; $40 \%$ for organizational capital and firm-specific

\footnotetext{
${ }^{6}$ Details on the exact procedure followed for each country and asset type can be obtained from the author upon request.
} 
human capital; $60 \%$ for brand names; and $13.75 \%$ for entertainment, artistic and literary originals, and mineral exploration. For the calculation of the intangible capital stock $R_{t}$, the PIM takes the following form:

$$
R_{t}=N_{t}+\left(1-\delta_{R}\right) R_{t-1}
$$

which assumes that (1) geometric depreciation, (2) constant depreciation rates over time, and (3) depreciation rates for each type of asset are the same for all countries. The real investment series for $\left(N_{t}\right)$ uses a GVA price deflator which is the same for all intangibles.

\subsection{A Note on the Construction of Intangible and Tangible Capital Services}

Data on intangible capital service services were generated according to the work by Oulton and Srinivasan (2003) and Marrano et al. (2009) and are consistent with the EU KLEMS approach (Timmer et al., 2007). This work contends that rather than using a wealth measure (such as the capital stock), it is vital to ascertain the flow of services a capital stock can provide to production. The technical steps of the construction of intangible and tangible capital services are in line with Roth and Thum (2013) and are explained in detail in Appendix 1.

\section{Descriptive Analysis}

Table 2.A1 in Appendix 2 shows the descriptive statistics of the analyzed dataset. Labor productivity growth increased by $0.1 \%$ points (from 1.5 to 1.6 ), or by $6.7 \%$, a slightly higher value than the value of $4.4 \%$ detected in previous work (Roth \& Thum, 2013, p. 498). Figure 2.1 shows the business intangible capital investment over GVA for the eight intangible capital indicators for the $16 \mathrm{EU}$ countries over the 16-year average time period 2000-2015. The figure shows that overall business intangible capital investments vary considerably across the 16 EU countries. Sweden ranks first with an investment of $17.1 \%$. This is similar to the findings by Edquist (2011), who reports an investment rate of 16, but higher than the findings by Roth and Thum (2013), who report an investment rate of $13.6 \%$ over business GVA. Sweden is followed by Finland, France, Denmark, and Ireland with investment rates of 15.6\%, $14.5 \%, 13.4 \%$, and $13.4 \%$ over GVA, respectively. Such values are again higher than those found by Roth and Thum (2013). In particular, the Irish case seems noteworthy, given its low values in the literature (Roth \& Thum, 2013, p. 498). Most countries' investment rates are positioned between $9 \%$ and $12 \%$, and therefore fall near the EU-16 average investment rate of $11 \%$. This is in the range of the value of $9.9 \%$, as 


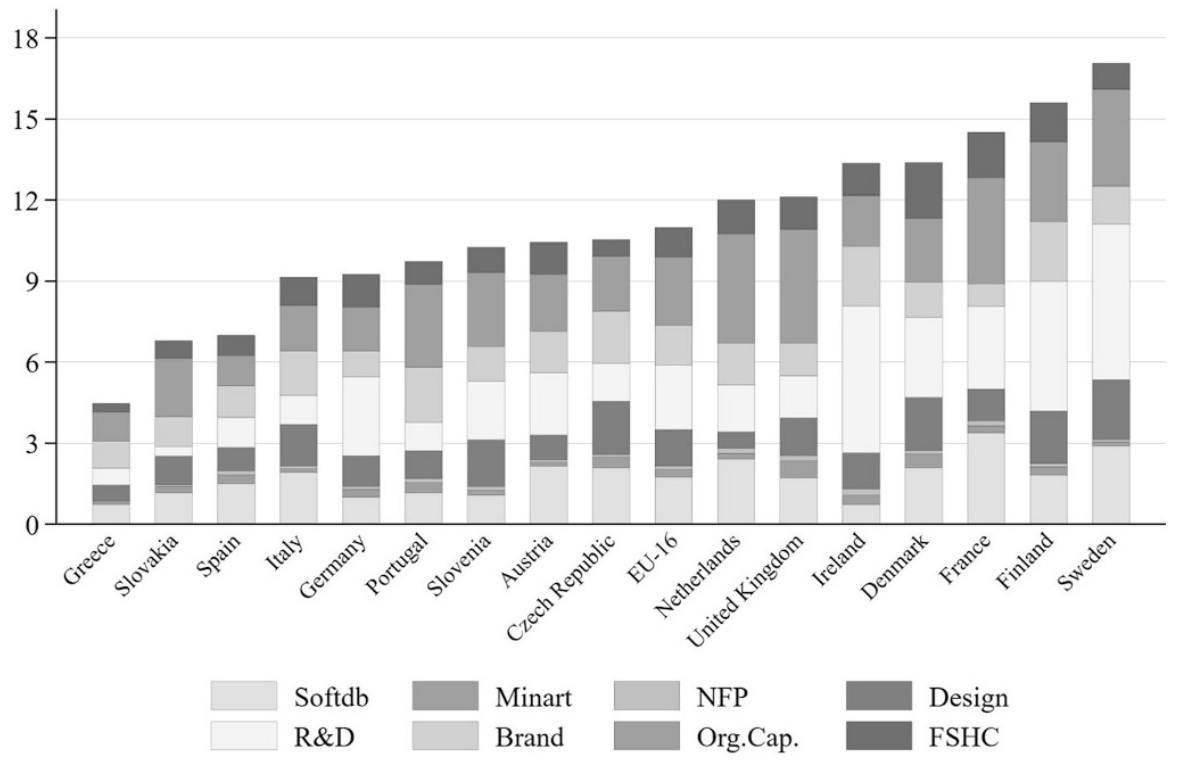

Fig. 2.1 Business intangible investment (as a percentage of GVA) in 16 EU countries, 2000-2015 Notes: Investments are compared to GVA (non-farm business sector b- $n+r-s$ excluding real estate activity). Softdb $=$ software and databases; Minart $=$ entertainment, artistic and literary originals, and mineral exploration; NFP $=$ new product development costs in the financial industry; Design $=$ design; R\&D = research and development; Brand = brand names; Org.Cap. = organizational capital; FSHC $=$ firm-specific human capital.

Sources: INTAN-Invest (NACE2) data (Corrado et al., 2018).

reported in earlier econometric work (Roth \& Thum, 2013, p. 498). The lowest investment levels can be detected in Spain, Slovakia, and Greece, with values of $7.0,6.8$, and 4.5 , respectively. Overall, it is noteworthy that the equal investment levels for Germany and Italy — with values of $9.3 \%$ and $9.2 \%$ - as well as the pronounced difference between Germany and France by $5.2 \%$ points, were not detected in the earlier literature using INNODRIVE data (Roth \& Thum, 2013, p. 498). ${ }^{7}$

In order to analyze the distribution of the three intangible dimensions, Fig. 2.2 displays a scatterplot between the innovative property and economic competencies. The five countries located in the upper-right corner-Sweden, Ireland, Finland, Denmark, and France — can be classified as highly innovative and strong investors in economic competencies. In addition, four out of these five countries score high on computerized information. There are some economies, however, that are highly

\footnotetext{
${ }^{7} \mathrm{~A}$ first comparison of the time series patterns of the INNODRIVE and INTAN-Invest (NACE2 rev.) in Fig. 2.A1 in Appendix 3 reveals that total intangible capital investment has strongly increased in the case of Italy, moderately increased in the case of France, and has not increased at all in the case of Germany, compared to the original INNODRIVE data. Future research should analyze these differences in more detail, by country and asset type.
} 


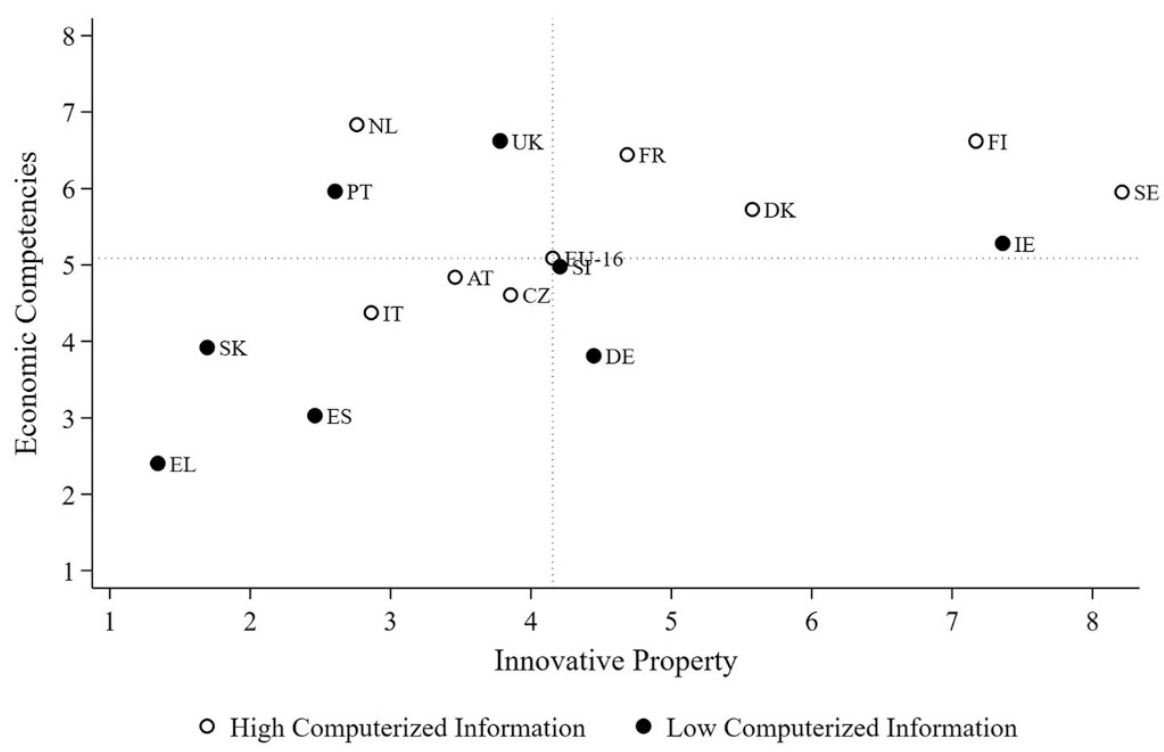

Fig. 2.2 Scatterplot between innovative property and economic competencies (as a percentage of GVA), 2000-2015

Notes: The dashed lines indicate the EU16 average values. AT $=$ Austria; $\mathrm{CZ}=$ Czech Republic; $\mathrm{DE}=$ Germany; $\mathrm{DK}=$ Denmark; $\mathrm{EL}=$ Greece $; \mathrm{ES}=$ Spain; FI $=$ Finland FR $=$ France IE $=$ Ireland; IT $=$ Italy; $\mathrm{NL}=$ the Netherlands; $\mathrm{PT}=$ Portugal; $\mathrm{SE}=$ Sweden; $\mathrm{SI}=$ Slovenia; $\mathrm{SK}=$ Slovakia; UK = United Kingdom.

Sources: INTAN-Invest (NACE2) data (Corrado et al., 2018).

innovative, but which invest less in economic competencies and computerized information, such as Germany. ${ }^{8}$ The third category includes countries that score low on innovative property but high on economic competencies, namely the UK, the Netherlands, and Portugal, of which only the Netherlands scores high on promoting computerized information. The fourth category contains countries that score low on both dimensions: Italy, Spain, Slovakia, and Greece. Three out of these four countries also score low on computerized information.

Figure 2.3 compares business investments in intangible and tangible capital as used in the econometric estimation. Once intangibles are included in the asset boundary of the national accounts, the average level of investment of the $16 \mathrm{EU}$ countries is $25.1 \%$. This value is significantly higher than the value produced if one only considers tangible capital investment, which would be at $14.1 \%$. Among the 16 EU countries, seven countries (Finland, France, Sweden, the Netherlands, the United Kingdom, Ireland, and Denmark) invest more in intangibles than in tangibles-their share of intangible/tangible investment is already greater than $1 \%$. This is in line with the finding by Nakamura (2010), who detected this pattern for the US as early as the year 2000 , but contrasts with an earlier analysis for the time period

\footnotetext{
${ }^{8}$ Germany's position might be related to the altered methodology in the INTAN-Invest (NACE2) dataset (Corrado et al., 2018) (see Fig. 2.A1 in Appendix 3).
} 


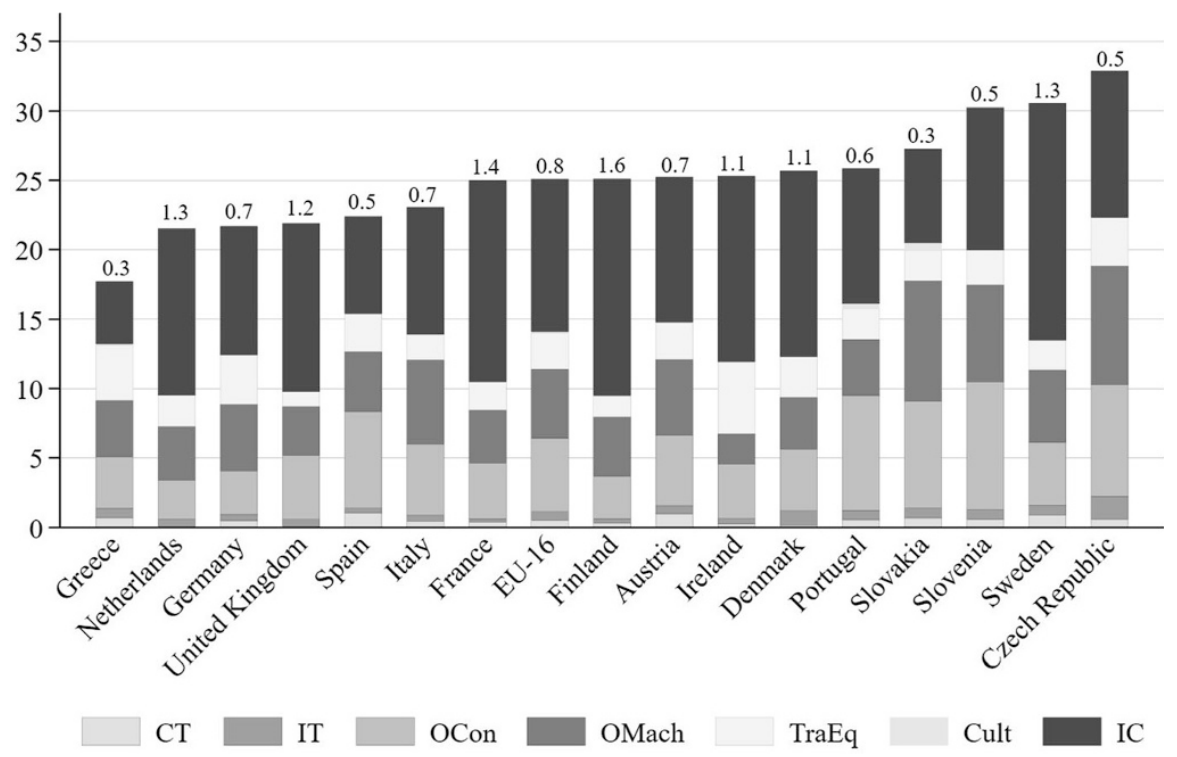

Fig. 2.3 Business tangible and intangible capital investments (as a percentage of GVA), EU16, 2000-2015

Notes: CT $=$ communications technology; IT $=$ information technology; OCon $=$ total nonresidential capital investment; OMach $=$ other machinery and equipment; TraEq $=$ transport equipment; Cult $=$ cultivated assets; IC $=$ intangible capital. Residential Structure has been excluded. Values on top of the bars depict the intangible/tangible capital investment ratio.

Sources: INTAN-Invest (NACE2) data (Corrado et al., 2018) and EUKLEMS data (Jäger, 2017).

1998-2005 (Roth \& Thum, 2013, p. 500), which did not find such a pronounced pattern. 9

Figure 2.4 shows the time series pattern for intangible and tangible capital investment and labor productivity growth for the 16 individual EU countries and the average EU-16 pattern. Three findings are especially noteworthy. First, in line with earlier literature (Corrado et al., 2018), when analyzing an average EU-16 time series pattern, the crisis has led to a slight decline in intangible capital investment but a more pronounced decline in tangible capital. Whereas intangible capital investments have swiftly recovered, tangible capital investments have not yet recovered to pre-crisis levels. Second, the decline in investment in tangible capital has been pronounced in EA countries due to the sovereign debt crisis, particularly in Greece, Spain, Italy, Portugal, and Slovenia. Conversely, with the exception of Greece, intangible capital investment has even increased in these countries in times of crisis and economic recovery. Third, the Irish case is exceptional. In times of economic recovery, Ireland has managed to more than double its intangible capital investments-largely due to significant investments in R\&D.

\footnotetext{
${ }^{9}$ Such contrasting findings might be related to the overall increase in total intangible capital investment in the INTAN-Invest dataset (NACE2), as displayed in Fig. 2.A1 in Appendix 3.
} 

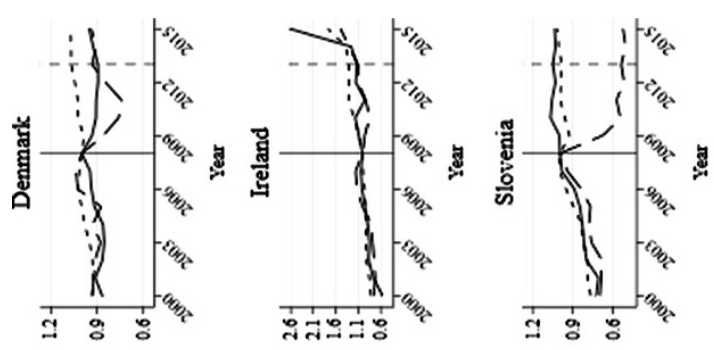

$\stackrel{\oplus}{\vec{F}}$

宅

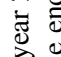

方

$\Xi$ 궁

월

害
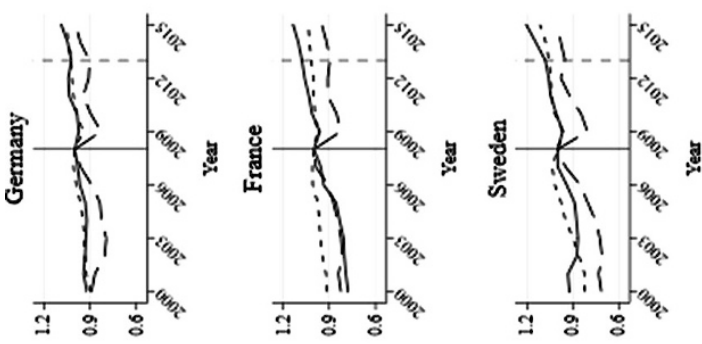

|
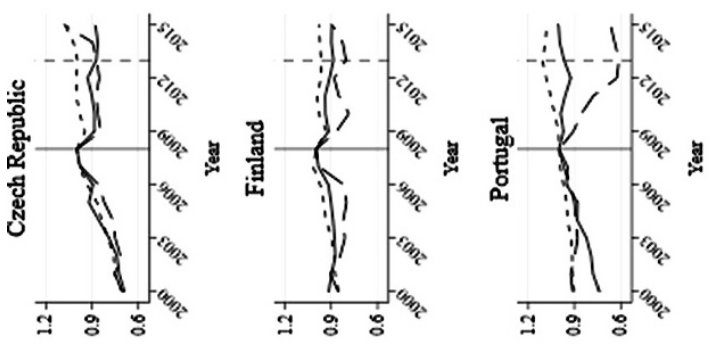

|

过

उั

次.

容言造

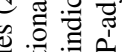

魚紫

言苍䒛

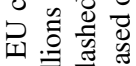

을 흠

\&. $\Xi$.

.

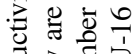

궁 홀

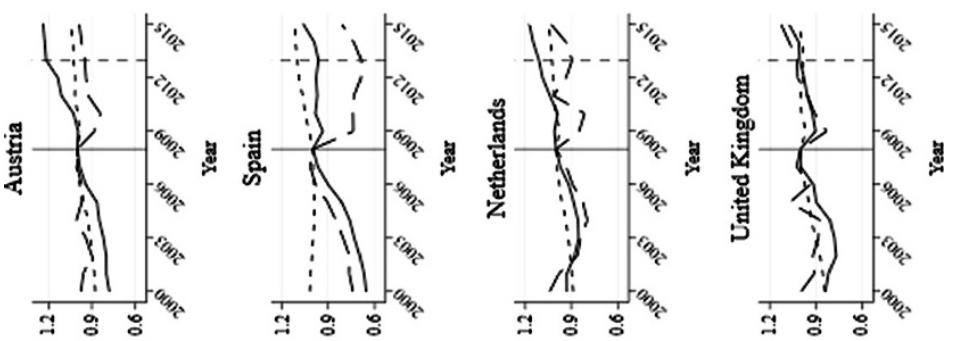

흘 䒕 ส 远元 志 음 可记 ส 은 5

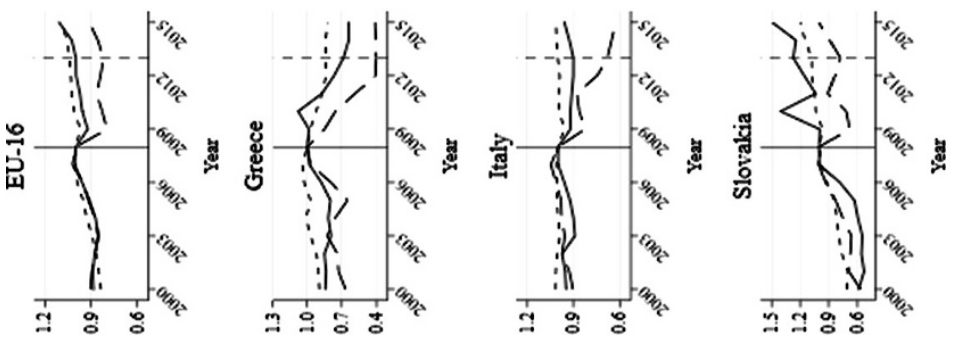

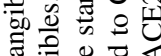
氜 思哥产范

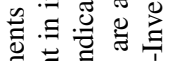
ㄹ.

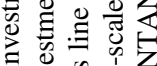

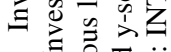

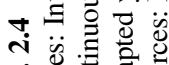

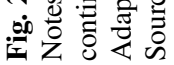




\section{Econometric Estimation}

We estimate eq. (2.1) with the help of a pooled panel (PP) estimation approach. ${ }^{10}$ To control for panel heteroscedasticity, a panel-corrected standard error estimation procedure (PCSE) was used. ${ }^{11}$ It should be noted that the PP-PCSE estimation yields the same coefficients as a random-effects estimator (see row 27 in Table 2.3). This property permits us to compare our results directly with the econometric findings of the existing literature (Roth \& Thum, 2013, pp. 501-505). Regression 2.1 in Table 2.2 shows the results when estimating a traditional production function without the inclusion of intangibles (excluding software, R\&D, and entertainment, artistic and literary originals, and mineral exploration from the tangible capital investment). Growth in tangible capital services is positively associated with labor productivity growth and has a coefficient of 0.31 , which explains a $64 \%$ share of labor productivity growth. ${ }^{12}$ Regression 2.2 includes intangibles. Growth in intangible capital services positively relates to labor productivity growth with a coefficient of a magnitude of 0.38 , explaining $66 \%$ of labor productivity growth. As can be inferred from Table 2.1, this value is higher than the figure of 50\% reported in earlier work (Roth \& Thum, 2013, p. 502). Once intangibles are included, the impact of tangible capital diminishes to $34 \%$, which is a slightly lower value than previously reported in the literature (Roth \& Thum, 2013, p. 503). ${ }^{13}$ This finding clarifies that intangible capital investments have become the dominant source of growth in EU countries.

Regression 3 in Table 2.2 analyzes the relationship between intangible capital and labor productivity during times of crisis by adding a crisis (2008-2013) interaction effect to the specification of regression 2. Regression 3 clarifies that while the relationship between tangible capital services growth and labor productivity growth actually turns negative in times of crisis, with a coefficient of $0.04(0.28-0.32)$, the relationship between intangible capital services growth and labor productivity growth remains positive with a coefficient of $0.20(0.48-0.28)$. To analyze this novel finding in more detail, regression 4 adds a recovery interaction effect

\footnotetext{
${ }^{10}$ Without a lagged initial income term on the left-hand side, the baseline model specification in eq. (2.1) may be estimated without the complexities of a dynamic panel analysis. When replicating the random-effects estimation by Roth and Thum (2013, pp. 501-505), a Breusch and Pagan LM test for random effects was performed via the post-estimation command "xttest0" (Stata Corporation, 2017). With a $\chi^{2}$ value of 0 , the rejection of the null hypothesis fails. This validates the usage of a pooled panel estimation approach.

${ }^{11}$ The PCSE calculation was performed via the "xtpcse" command (Stata Corporation, 2017).

${ }^{12}$ Taking eq. (2.1) as our reference, with the mean value of $\left(\ln q_{i, t}-\ln q_{i, t-1}\right)$ being 1.5 , the mean value of $\left(\ln k_{i, t}-\ln k_{i, t-1}\right)$ being 3.1 , and $\alpha$ being 0.31 , the calculation can be set up as follows: $(0.31 * 3.1) / 1.5=0.64$.

${ }^{13}$ When controlling for Ireland in 2015 (see row 2 in Table 2.3 and Fig. 2.4), intangible capital services explain $46 \%$ of labor productivity growth. This value is closer to the $50 \%$ finding by Roth and Thum (2013, p. 502). Growth in tangible capital services and TFP then explains $31 \%$ and $23 \%$, respectively.
} 
Table 2.2 Intangibles and labor productivity growth, 2000-2015, PP-PCSE estimation

\begin{tabular}{|c|c|c|c|c|c|c|}
\hline Estimation method & $\begin{array}{l}\text { PP- } \\
\text { PCSE }\end{array}$ & $\begin{array}{l}\text { PP- } \\
\text { PCSE }\end{array}$ & $\begin{array}{l}\text { PP- } \\
\text { PCSE }\end{array}$ & $\begin{array}{l}\text { PP- } \\
\text { PCSE }\end{array}$ & $\begin{array}{l}\text { PP- } \\
\text { PCSE }\end{array}$ & 2SLS \\
\hline Time sample & $\begin{array}{l}2000- \\
2015\end{array}$ & $\begin{array}{l}2000- \\
2015\end{array}$ & $\begin{array}{l}2000- \\
2015\end{array}$ & $\begin{array}{l}2008- \\
2015\end{array}$ & $\begin{array}{l}2000- \\
2015\end{array}$ & $\begin{array}{l}2000- \\
2015\end{array}$ \\
\hline Equation & (1) & (2) & (3) & (4) & (5) & $(6)$ \\
\hline \multirow{2}{*}{$\begin{array}{l}\text { Tangible services } \\
\text { growth }\end{array}$} & $0.31 * * *$ & $0.19 * *$ & $0.28 * * *$ & -0.13 & $0.18 * *$ & 0.58 \\
\hline & $(0.08)$ & $(0.08)$ & $(0.08)$ & $(0.15)$ & $(0.07)$ & $(0.42)$ \\
\hline \multirow{2}{*}{$\begin{array}{l}\text { Tangible services } \\
\text { growth*crisis }\end{array}$} & - & - & $-0.32 * *$ & - & - & - \\
\hline & & & $(0.13)$ & & & \\
\hline \multirow{2}{*}{$\begin{array}{l}\text { Tangible services } \\
\text { growth*recovery }\end{array}$} & - & - & - & 0.47 & - & - \\
\hline & & & & $(0.30)$ & & \\
\hline \multirow{2}{*}{$\begin{array}{l}\text { Intangible services } \\
\text { growth }\end{array}$} & - & $0.38 * * *$ & $0.48 * * *$ & $0.32^{* * *}$ & - & $0.50 * * *$ \\
\hline & & $(0.07)$ & $(0.09)$ & $(0.11)$ & & $(0.16)$ \\
\hline \multirow{2}{*}{$\begin{array}{l}\text { Intangible services } \\
\text { growth*crisis }\end{array}$} & - & - & $-0.28 * *$ & - & - & - \\
\hline & & & $(0.13)$ & & & \\
\hline \multirow{2}{*}{$\begin{array}{l}\text { Intangible services } \\
\text { growth*recovery }\end{array}$} & - & - & - & $0.42 *$ & - & - \\
\hline & & & & $(0.23)$ & & \\
\hline \multirow{2}{*}{$\begin{array}{l}\text { Innovative property } \\
\text { services growth }\end{array}$} & - & - & - & - & $0.37 * * *$ & - \\
\hline & & & & & $(0.07)$ & \\
\hline \multirow{2}{*}{$\begin{array}{l}\text { Computerized informa- } \\
\text { tion services growth }\end{array}$} & - & - & - & - & -0.01 & - \\
\hline & & & & & $(0.04)$ & \\
\hline \multirow{2}{*}{$\begin{array}{l}\text { Economic competencies } \\
\text { services growth }\end{array}$} & - & - & - & - & 0.02 & - \\
\hline & & & & & $(0.06)$ & \\
\hline \multirow{2}{*}{$\begin{array}{l}\text { Upper secondary } \\
\text { education } 15+\end{array}$} & $0.07 * * *$ & $0.05^{* * *}$ & $0.05 * * *$ & 0.02 & $0.06^{* * *}$ & $0.07 * * *$ \\
\hline & $(0.02)$ & $(0.01)$ & $(0.01)$ & $(0.02)$ & $(0.01)$ & $(0.02)$ \\
\hline \multirow[t]{2}{*}{ Catch-up } & $-0.02 * *$ & $-0.02 * * *$ & $-0.02 * * *$ & -0.01 & $-0.02 * *$ & $-0.02 *$ \\
\hline & $(0.01)$ & $(0.01)$ & $(0.01)$ & $(0.01)$ & $(0.01)$ & $(0.01)$ \\
\hline \multirow[t]{2}{*}{ Business cycle } & $-0.11 *$ & $-0.12 *$ & $-0.13 * *$ & $-0.13^{*}$ & $-0.12 *$ & $-0.11^{* *}$ \\
\hline & $(0.06)$ & $(0.06)$ & $(0.06)$ & $(0.07)$ & $(0.06)$ & $(0.05)$ \\
\hline R-squared & 0.40 & 0.50 & 0.54 & 0.63 & 0.54 & 0.46 \\
\hline Observations & 256 & 256 & 256 & 128 & 256 & 208 \\
\hline Number of countries & 16 & 16 & 16 & 16 & 16 & 16 \\
\hline
\end{tabular}

Notes: In regression (2.1), tangible services growth, labor productivity growth, and the catch-up term exclude software, R\&D, and entertainment, artistic and literary originals, and mineral exploration. In regressions, (2-6) labor productivity growth and the catch-up term are expanded with intangible capital. Tangible capital excludes residential capital. Labor productivity growth was calculated based on the GVA of the non-farm business sectors $b-n+r-s$ (excluding real estate activities). ***p $<0.01, * * \mathrm{p}<0,05, * \mathrm{p}<0.1$

(2014-2015) to a crisis-recovery sub-sample (2008-2015). Regression 4 clarifies that in times of economic recovery, intangible capital services growth has a strong positive relationship to labor productivity growth. This finding is particularly evident in Ireland in 2015, where a large intangible service growth (20\%) is related to a large labor productivity growth of (25.8\%) (see rows 2 and 3 in Table 2.3 and Fig. 2.4). 
Table 2.3 Sensitivity analysis for the baseline PP-PCSE estimator

\begin{tabular}{|c|c|c|c|c|c|}
\hline Row & Specification change & $\begin{array}{l}\text { Coefficient on } \\
\text { intangibles }\end{array}$ & Countries & Obs. & R-squared \\
\hline \multicolumn{6}{|c|}{ Baseline regression } \\
\hline (1) & Baseline-regression & $0.38 * * *$ & 16 & 256 & 0.50 \\
\hline \multicolumn{6}{|c|}{ Influential cases } \\
\hline (2) & Including Irish 2015 Dummy & $0.26 * * *$ & 16 & 256 & 0.59 \\
\hline (3) & Excluding Ireland & $0.24 * * *$ & 15 & 240 & 0.48 \\
\hline (4) & Excluding Greece & $0.44 * * *$ & 15 & 240 & 0.56 \\
\hline (5) & Excluding Greece and Ireland & $0.28 * * *$ & 14 & 224 & 0.56 \\
\hline (6) & Excluding New Member States & $0.37 * * *$ & 13 & 208 & 0.53 \\
\hline
\end{tabular}

Restructuring of country sample

\begin{tabular}{l|l|l|l|l|l}
\hline$(7)$ & 13 EU countries, 2000-2015 & $0.52 * * *$ & 13 & 208 & 0.65 \\
\hline$(8)$ & $\begin{array}{l}\text { Dummy for coordinated } \\
\text { economies }\end{array}$ & $0.37 * * *$ & 16 & 256 & 0.51 \\
\hline$(9)$ & $\begin{array}{l}\text { Dummy for Mediterranean } \\
\text { countries }\end{array}$ & $0.37 * * *$ & 16 & 256 & 0.50 \\
\hline$(10)$ & Dummy for New Member States & $0.33^{* * *}$ & 16 & 256 & 0.53 \\
\hline$(11)$ & $\begin{array}{l}\text { Dummy for Scandinavian } \\
\text { countries }\end{array}$ & $0.37 * * *$ & 16 & 256 & 0.50 \\
\hline$(12)$ & Dummy for liberal economies & $0.37^{* * *}$ & 16 & 256 & 0.50 \\
\hline
\end{tabular}

Specifications

\begin{tabular}{l|l|l|l|l|l}
\hline$(13)$ & Rule of Law & $0.37 * * *$ & 16 & 240 & 0.51 \\
\hline$(14)$ & Openness to Trade & $0.33^{* * *}$ & 16 & 256 & 0.53 \\
\hline$(15)$ & FDI & $0.39^{* * *}$ & 16 & 241 & 0.54 \\
\hline$(16)$ & Government Expenditures & $0.35^{* * *}$ & 16 & 256 & 0.52 \\
\hline$(17)$ & Social Expenditures & $0.31^{* * *}$ & 16 & 256 & 0.54 \\
\hline$(18)$ & Education Expenditures & $0.41^{* * *}$ & 16 & 241 & 0.57 \\
\hline$(19)$ & Inflation & $0.38^{* * *}$ & 16 & 256 & 0.53 \\
\hline$(20)$ & Income Tax & $0.36^{* * *}$ & 16 & 256 & 0.50 \\
\hline$(21)$ & Stock Market Capitalization & $0.38^{* * *}$ & 16 & 204 & 0.50 \\
\hline$(22)$ & Alternative Business cycle & $0.38^{* * *}$ & 16 & 256 & 0.50 \\
\hline
\end{tabular}

Other independent variables

\begin{tabular}{|c|c|c|c|c|c|}
\hline (23) & Without Ireland (Inno. Prop.) & 0.11 & \multirow[t]{3}{*}{16} & \multirow[t]{3}{*}{240} & \multirow[t]{3}{*}{0.50} \\
\hline (24) & $\begin{array}{l}\text { Without Ireland (Computerized } \\
\text { Information) }\end{array}$ & -0.01 & & & \\
\hline (25) & $\begin{array}{l}\text { Without Ireland (Economic } \\
\text { Competencies) }\end{array}$ & $0.17 * * *$ & & & \\
\hline \multicolumn{6}{|c|}{ Methods } \\
\hline (26) & Panel Autocorrelation-Order 1 & $0.40 * * *$ & 16 & 256 & 0.58 \\
\hline (27) & Random-Effects & $0.38 * * *$ & 16 & 256 & 0.51 \\
\hline
\end{tabular}

Notes: The random-effects estimator depicts an overall R-Square value. $* * * p<0.01, * * p<0,05$, $* \mathrm{p}<0.1$. Obs. $=$ Observations. 
Regression 5 assesses which dimensions of intangible capital services are the key drivers for the positive relationship between intangible capital and labor productivity growth. It includes 1) computerized information, 2) innovative property, and 3) economic competencies. In contrast to earlier work (Roth \& Thum, 2013, p. 503), which finds economic competencies to be the main driver, we now find innovative property to be a strong driver $(0.37)$ of labor productivity growth. This relationship describes the evidence in the Irish case in 2015, in which a large share of innovative property services growth is related to a large labor productivity growth. Excluding Ireland in rows $23-25$ in Table 2.3 renders innovative property insignificant and re-establishes economic competencies with a coefficient of 0.17 as the main driver. In order to control for potential endogeneity, regression 6 estimates eq. (2.1) with the help of a 2SLS estimation approach and 208 overall observations. Following earlier econometric work by Roth and Thum (2013, p. 503), lagged levels of intangible and tangible capital as instruments were chosen. ${ }^{14}$ The results clarify that while the relationship between tangible capital and labor productivity growth is rendered insignificant after controlling for endogeneity, the coefficient for intangible capital services growth remains highly significant, yielding a further increase in magnitude (0.50). The sensitivity analysis in Table 2.3 further explores the robustness of the coefficient of intangible capital on labor productivity growth, from regression 2, permitting us to conduct an analysis with a maximum of 256 observations.

Table 2.3 displays a sensitivity analysis of regression 2 in Table 2.2. The first row shows the coefficient for the Baseline regression, regression 2 in Table 2.2. Rows 2-6 analyze the sensitivity due to influential cases. ${ }^{15}$ When controlling for Ireland in 2015, as expected, the intangible capital coefficient declines (0.26), explaining a $46 \%$ share of labor productivity growth. A similar decline in magnitude $(0.24$ and 0.28 ) is found when excluding Ireland or Ireland and Greece from the country sample in rows 3 and 5. Excluding Greece in row 4 yields a higher coefficient (0.44). Excluding the three new member states in row 6 yields a slight reduction of the coefficient (0.37). Rows 7-12 restructure the country sample and analyze five distinct European regime dummies. When analyzing the 13 EU countries from 2000 to 2015 from earlier work (Roth \& Thum, 2013), the relationship remains highly significant and reveals an increase in magnitude (0.52). Neither controlling for the five European regime dummies in rows 8-12, nor altering the model specifications in rows 13-22, nor using alternative estimation approaches in rows 26-27 alters the significance of the relationship between intangible capital and labor productivity in any appreciable manner, although the magnitude of the relationship varies slightly.

\footnotetext{
${ }^{14}$ To be precise, the first two lagged levels were used. A Wooldridge robust score test of overidentifying restrictions was performed via the 2SLS post-estimation command "estat overid" (Stata Corporation, 2017). With a $\chi^{2}(2)$ value of 0.4 , the rejection of the null hypothesis fails. This indicates that the instruments used are valid.

${ }^{15}$ The influential cases of Ireland and Greece have been detected via the "avplot" command (Stata Corporation, 2017), as well as from Fig. 2.4.
} 


\section{Conclusions}

This contribution analyzes the relationship between intangible capital investment by businesses and labor productivity growth by analyzing an EU-16 country sample over the time period 2000-2015, with the help of a cross-country growth-accounting estimation approach. By matching the most recent release of the INTAN-Invest (NACE2) dataset (Corrado et al., 2018) with the latest data available from the EU KLEMS dataset (Jäger, 2017) alongside a wide range of growth-relevant policy variables from Eurostat, the OECD, and the World Bank, this contribution generates the largest and most up-to-date panel dataset developed on intangible capital at the macro-level, based on a total of 256 country observations.

This contribution reaches three major findings. First, in line with previous growth econometric literature (Roth \& Thum, 2013), this contribution confirms that once intangibles are factored into the calculations, they become the dominant source-up to $66 \%$ - of labor productivity growth in the EU. Second, when focussing on times of crisis (2008-2013), this contribution finds that whereas the relationship between tangible capital and labor productivity turned negative, the impact of intangibles on growth remained solidly positive throughout this period. Thirdly, when accounting for the economic recovery (2014-2015), this contribution establishes a highly significant and remarkably strong relationship between intangible capital and labor productivity growth.

In light of these novel empirical results, four main policy conclusions can be drawn from our analysis of European economies. First, given the paucity of econometric findings in the literature analyzing the relationship between intangible capital and labor productivity growth at the macro-level, additional research should be devoted in the future to further econometrically corroborate the positive relationship between intangible capital and labor productivity. This future research should examine in more detail the evolutionary changes in existing cross-country intangible capital datasets, by country and by asset type. Second, as developed economies transition into knowledge societies, it is essential to incorporate a complete set of intangibles-including branding, firm-specific human capital, and organizational capital-into today's national accounting framework in order to acknowledge the pronounced shift in investment patterns from tangible to intangible investment in contemporary national accounting frameworks. The current frameworks are inadequate, as they under-represent actual levels of capital investment in European economies. Their reported levels of capital investment would undoubtedly be greater once the full range of investment in intangible capital is incorporated into the accounting framework.

Third, the incorporation of a broader dimension of innovation investment seems to be an important first step in revising today's national accounting framework, particularly when focusing on the business sector. Moreover, a follow-up step consists of broadly adapting the national accounting framework to reflect environmental, health, and public intangible capital investment. Fourth, government policies that actively support the accumulation of business intangibles should be designed 
and implemented as soon as possible. This will foremost require government investment in public intangibles, such as enhancing the quantity and quality of a highly skilled labor force, well-functioning formal and informal institutions, and a well-designed policy framework that includes credible financial conditions and an effective scheme offering intangible tax incentives at the member state and EU level. ${ }^{16}$

\section{Appendix 1 Construction of Intangible and Tangible Capital Services Growth}

Following Oulton and Srinivasan (2003), Marrano et al. (2009) and the EU KLEMS approach (Timmer et al., 2007) and consistent with Roth and Thum (2013), tangible and intangible capital services growth $\left(\ln k_{i, t}-\ln k_{i, t-1}\right)$ and $\left(\ln r_{i, t}-\ln r_{i, t-1}\right)$ or respectively $\Delta \ln k_{i, t}$ and $\Delta \ln r_{i, t}$ are defined as:

$$
\begin{aligned}
\Delta \ln k_{i, t} & =\sum_{i=1}^{m} \bar{\nu}_{i, t} \Delta \ln a_{i, t} \\
\Delta \ln r_{i, t} & =\sum_{i=m+1}^{n} \bar{\nu}_{i, t} \Delta \ln a_{i, t}
\end{aligned}
$$

where $a_{i, t}$ is the asset-specific capital stock, as calculated with the PIM, assets from 1 to $m$ are tangible assets, and assets from $m+1$ to $n$ are intangible. Lower case $k_{i, t}$, $r_{i, t}$ and $a_{i, t}$ indicate that the variables are scaled on hours worked. $\bar{\nu}_{i, t}$ is a 2-year average weighting term defined as:

$$
\bar{\nu}_{i, t}=\frac{1}{2}\left[\nu_{i, t}+\nu_{i, t-1}\right]
$$

The term $\nu_{i, t}$ is computed as:

$$
\nu_{i, t}=\left(\frac{p_{i, t}^{a} a_{i, t}}{\sum_{i=1}^{n} p_{i, t}^{a} a_{i, t}}\right)
$$

\footnotetext{
${ }^{16}$ See here Gros and Roth (2012); Haskel and Westlake (2018); Roth (2019); and Thum-Thysen et al. (2019).
} 
From (2.A4), $a_{i, t}$ is the asset-specific capital stock and $p_{i, t}^{a}$ is the asset-specific (tangible or intangible) user cost. The latter user cost is defined as:

$$
p_{i, t}^{a}=p_{i, t-1}^{I} i_{t}+\delta_{i, t} p_{i, t}^{I}-\left[p_{i, t}^{I}-p_{i, t-1}^{I}\right]
$$

where $p_{i, t-1}^{I}$ is the investment price, constructed from the price index of the GFCF series at chained prices, $i_{t}$ is the time-specific rate of return (common to all tangible and intangible assets) and $\delta_{i, t}$ is the time variant and asset-specific depreciation rate. The depreciation rate that varies over time reflects the varying contribution over time of industries to the total non-farm business sector $(b-n+r-s$ excluding real estate activities). The time-varying depreciation rate used here is defined as:

$$
\delta_{i, t}=\frac{A_{i, t-1}+I_{i, t}-A_{i, t}}{A_{i, t-1}}
$$

The last term in (A5) is the capital gain term $\left[p_{i, t}^{I}-p_{i, t-1}^{I}\right]$; following Niebel and Saam (2011), it is computed considering the price indices of three consecutive periods using the formula:

$$
\left[p_{i, t}^{I}-p_{i, t-1}^{I}\right]=\frac{1}{2}\left(\ln \left(p_{i, t}\right)-\ln \left(p_{i, t-2}\right)\right) p_{i, t-1}
$$

The rate of return $i_{t}$ is common to all the tangible and intangible assets and represents the overall return on the investment under the profit maximization assumption, as explained in Oulton and Srinivasan (2003). Following Timmer et al. (2007), the common rate of return is computed here using an ex-post approach that accounts for the rental payments of each asset:

$$
i_{t}=\frac{p_{t}^{a} a_{t}+\sum_{i}\left[p_{i, t}^{I}-p_{i, t-1}^{I}\right] a_{i, t}-\sum_{i} p_{i, t}^{I} \delta_{i, t} a_{i, t}}{\sum_{i} p_{i, t-1}^{I} a_{i, t}}
$$

where $p_{t}^{a} a_{t}$ is the total nominal capital compensation, obtained by subtracting the labor compensation from the GVA. 


\section{Appendix 2 Descriptive Statistics}

Table 2.A1 Descriptive statistics, EU16, 2000-2015

\begin{tabular}{l|l|l|l|l|l}
\hline & Obs. & Mean & $\begin{array}{l}\text { Standard } \\
\text { deviation }\end{array}$ & Min. & Max. \\
\hline LPG-expanded by intangibles (in \%) & 256 & 1.6 & 3.1 & -7.6 & 25.8 \\
\hline LPG-excluding all intangibles (in \%) & 256 & 1.5 & 3.0 & -8.7 & 16.7 \\
\hline Intangible services growth (in \%) & 256 & 2.8 & 3.4 & -7.9 & 20 \\
\hline Tangible services growth (in \%) & 256 & 3.1 & 2.9 & -4.4 & 13.8 \\
\hline $\begin{array}{l}\text { Tangible services growth-expanded by intan- } \\
\text { gibles (in \%) }\end{array}$ & 256 & 2.9 & 3.0 & -5.8 & 13.3 \\
\hline Innovative property services growth (in \%) & 256 & 4.0 & 4.3 & -8.2 & 33.5 \\
\hline $\begin{array}{l}\text { Economic competencies services growth } \\
\text { (in \%) }\end{array}$ & 256 & 1.4 & 3.8 & -13.0 & 17 \\
\hline $\begin{array}{l}\text { Computerized information services growth } \\
\text { (in \%) }\end{array}$ & 256 & 3.9 & 6.4 & -18.4 & 40.1 \\
\hline Upper-secondary education 15+ (in \%) & 256 & 67.8 & 14.2 & 21 & 87.6 \\
\hline $\begin{array}{l}\text { Interaction education and catch-up-expanded } \\
\text { by intangibles }\end{array}$ & 256 & 34.7 & 35.0 & 0 & 197.2 \\
\hline $\begin{array}{l}\text { Interaction education and catch-up-excluding } \\
\text { all intangibles }\end{array}$ & 256 & 31.8 & 30.4 & 0 & 158.1 \\
\hline Business cycle (in \%) & 256 & 91.2 & 4.5 & 72.5 & 96.9 \\
\hline Rule of law & 240 & 1.4 & 0.5 & 0.3 & 2.1 \\
\hline Openness (in \%) & 256 & 92.3 & 39 & 45.6 & 215.4 \\
\hline $\begin{array}{l}\text { FDI (main balance of payments as a \% of } \\
\text { GDP) }\end{array}$ & 241 & -0.4 & 5.2 & -15.2 & 10.2 \\
\hline Government expenditure (as a \% of GDP) & 256 & 47.1 & 5.9 & 29 & 65.1 \\
\hline Social expenditure (as a \% of GDP) & 256 & 25.3 & 4.7 & 14.8 & 34.5 \\
\hline Education expenditure (as a \% of GDP) & 241 & 5.3 & 1.2 & 3 & 8.8 \\
\hline Inflation (in \%) & 256 & 2.2 & 1.7 & -1.7 & 12.2 \\
\hline Income tax (as a \% of GDP) & 256 & 8.9 & 5.0 & 2.6 & 26.3 \\
\hline Stock market capitalization (as a \% of GDP) & 204 & 52.8 & 36.2 & 1.5 & 233.9 \\
\hline Nos: LPG & & & & & \\
\hline
\end{tabular}

Notes: $\mathrm{LPG}=$ Labor Productivity Growth; Obs. $=$ Observations; Min. $=$ Minimum; Max. $=$ Maximum. 


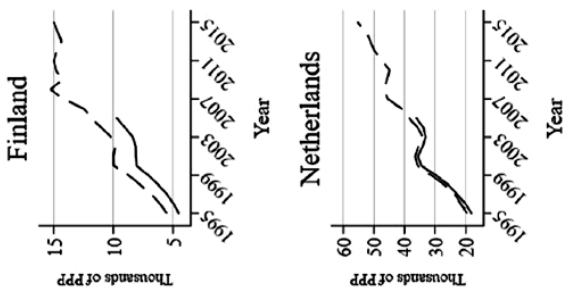

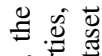

$\therefore$ 要 전

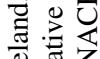
$\exists$ o 珹宝 药

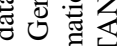
政宫宗 记

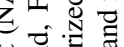
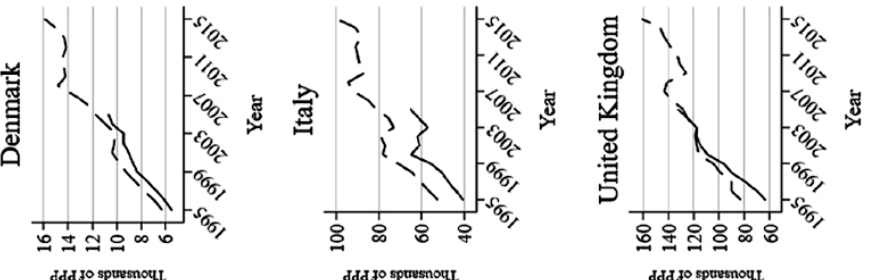

要 贯 을
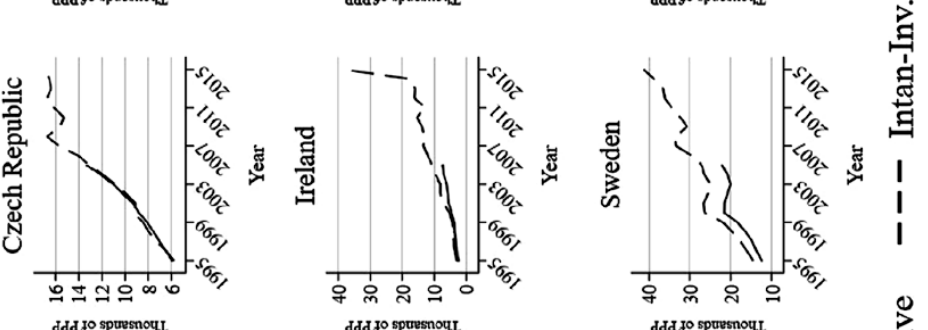

된

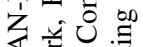

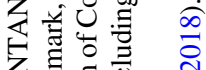

$\stackrel{\infty}{\infty}$

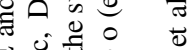

II :을

年

8

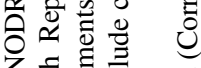

帘

בְ'
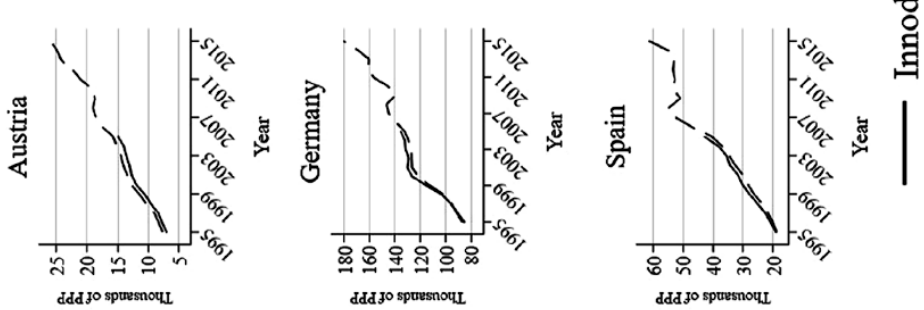

讨

엉

造

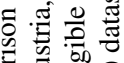

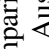
政

类 西

吸

ส

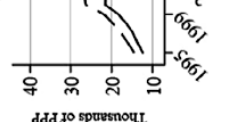

棓

1 은 준

ลे

in

跣

ส

क्षे

过艺

政

$\Xi$ 过

空.

的定

के जी

贯 की

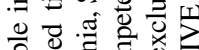

bo

产 0 o

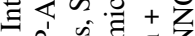

二公完

त

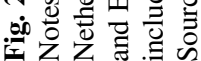




\section{References}

Abowd, J. M., Haltiwanger, J., Jarmin, R., Lane, J., Lengermann, P., McCue, K., McKinney, K., \& Sandusky, K. (2005). The relationship among human capital, productivity and market value. In C. Corrado, J. Haltiwanger, \& D. Sichel (Eds.), Measuring capital in the new economy (pp. 153-204). University of Chicago Press.

Bounfour, A., \& Miyagawa, T. (2015). Intangibles, market failure and innovation growth (pp. 1-10). Springer Verlag.

Brynjolfsson, E., Hitt, L. M., \& Yang, S. (2002). Intangible assets: Computers and organizational capital. Brookings Papers on Economic Activity, (1), 137-198.

Cañibano, L., Garcia-Ayuso, M., \& Sánchez, P. (2000). Accounting for intangibles: A literature review. Journal of Accounting Literature, 19, 102-130.

Corrado, C., Hulten, C., \& Sichel, D. (2005). Measuring capital and technology: An expanded framework. In C. Corrado, J. Haltiwanger, \& D. Sichel (Eds.), Measuring capital in the new economy (pp. 11-46). University of Chicago Press.

Corrado, C., Hulten, C., \& Sichel, D. (2009). Intangible capital and U.S. economic growth. Review of Income and Wealth, 55(3), 661-685.

Corrado, C., Haskel, J., Jona-Lasinio, C., \& Iommi, M. (2013). Innovation and intangible investment in Europe, Japan, and the United States. Oxford Review of Economic Policy, 29(2), 261-286.

Corrado, C., Haskel, J., Jona-Lasinio, C., \& Iommi, M. (2016). Intangible investment in the EU and US before and since the great recession and its contribution to productivity growth. EIB Working Papers No. 2016/08. European Investment Bank, Luxembourg. Available at: http:// hdl.handle.net/10419/149979.

Corrado, C., Haskel, J., Jona-Lasinio, C., \& Iommi, M. (2018). Intangible investment in the EU and US before and since the great recession and its contribution to productivity growth. Journal of Infrastructure Policy and Development, 2(1), 11-36.

Delbecque, V., Bounfour, A., \& Barreneche, A. (2015). Intangibles and value creation at the industrial level: Delineating their complementarities. In A. Bounfour \& T. Miyagawa (Eds.), Intangibles, market failure and innovation growth (pp. 27-56). Springer Verlag.

Edquist, H. (2011). Can investment in intangibles explain the Swedish productivity boom in the 1990s? Review of Income and Wealth, 57(4), 658-682.

Fukao, K., Miyagawa, T., Mukai, K., Shinoda, Y., \& Tonogi, K. (2009). Intangible investment in Japan: Measurement and contribution to economic growth. Review of Income and Wealth, 55(3), 717-736.

Gros, D., \& Roth, F. (2012). The Europe 2020 strategy: Is it capable of maintaining the EU's competitiveness in the world? Centre for European Policy Studies.

Guellec, D., \& van Pottelsberghe de la Potterie, B. (2001). R\&D and productivity growth: Panel data analysis of 16 OECD countries. OECD Economic Studies, 33, 103-126.

Haskel, J., \& Westlake, S. (2018). Capitalism without capital. Princeton University Press.

INNODRIVE. (2011). INNODRIVE intangibles database. Available at: https://cordis.europa.eu/ project/id/214576/reporting/de.

Jäger, K. (2017). EU KLEMS growth and productivity accounts 2017 release - description of methodology and general notes. Available at: http://www.euklems.net/TCB/2017/ Metholology_EU\%20KLEMS_2017.pdf.

Jona-Lasinio, C., Massimiliano, I., \& Roth, F. (2011). National measures of intangible capital in the EU-27. In H. Piekkola (Ed.), Intangible capital-Driver of growth in Europe, Proceedings of the University of Vaasa Reports 167 (pp. 20-62). University of Vaasa.

Kaufmann, D., Kraay, A., \& Mastruzzi, M. (2010). "The worldwide governance indicators: A summary of methodology, data and analytical issues", World Bank Policy Research Working Paper No. 5430. World Bank. 
Lev, B., \& Radhakrishnan, S. (2005). The valuation of organizational capital. In C. Corrado, J. Haltiwanger, \& D. Sichel (Eds.), Measuring capital in the new economy (pp. 73-110). University Chicago Press.

Marrano, M., Haskel, J., \& Wallis, G. (2009). What happened to the knowledge economy? ICT, intangible investment, and Britain's productivity record revisited. Review of Income and Wealth, 55(3), 686-716.

Miyagawa, T., \& Hisa, S. (2013). Estimates of intangible investment by industry and productivity growth in Japan. Japanese Economic Review, 64(1), 42-72.

Nakamura, L. (2001). "What is the U.S. gross investment in intangibles? (at least) one trillion dollars a year!", Working Papers 01-15. Federal Reserve Bank of Philadelphia.

Nakamura, L. (2010). Intangible assets and national income accounting. Review of Income and Wealth, 56(1), S135-S155.

Niebel, T., \& Saam, M. (2011). "Productivity of ICT and non-ICT capital: The role of rates of return and capital prices", ZEW Discussion Papers, no, 11-083. Mannheim.

Niebel, T., O'Mahony, M., \& Saam, M. (2017). “The contribution of intangible assets to sectoral productivity growth in the EU". Review of Income and Wealth Series, 63, S49-S67.

Oulton, N., \& Srinivasan, S. (2003). "Capital stocks, capital services, and depreciation: An integrated framework", Bank of England working paper no. 192. Bank of England.

Piekkola, H. (2016). Intangible investment and market valuation. Review of Income and Wealth, 62(1), 28-51.

Piekkola, H. (2018). Broad-based intangibles as generators of growth in Europe. Economics of Innovation and New Technology, 27(4), 377-400.

Roth, F. (2019). "Intangible capital and labour productivity growth: A review of the literature", Hamburg discussion papers in international economics, no. 4. University of Hamburg.

Roth, F., \& Thum, A. E. (2013). Intangible capital and labour productivity growth-panel evidence for the EU from 1998-2005. Review of Income and Wealth, 59(3), 486-508.

Corporation, S. (2017). Stata longitudinal-data/panel-data reference manual release 15. Stata Press.

Temple, J. (1999). The new growth evidence. Journal of Economic Literature, 37(1), 112-156.

Thum-Thysen, A.-E., Voigt, P., Bilbao-Osorio, B., Maier, C., \& Ognyanova, D. (2019). Investment dynamics in Europe: Distinct drivers and barriers for investing in intangible versus tangible assets? Structural Change and Economic Dynamics, 51, 77-88.

Timmer, M., van Moergastel, T., Stuivenwold, E., Ypma, G., O’Mahony, M., \& Kangasniemi, M. (2007). EU KLEMS growth and productivity accounts, version 1.0, part I: Methodology, EU KLEMS deliverable.

Van Ark, B. (2016). Europe's productivity slowdown revisited: A comparative perspective to the United States. In P. Askenazy, L. Bellmann, A. Bryson, \& E. Moreno Galbis (Eds.), Productivity puzzles across Europe (pp. 26-48). Oxford University Press.

Van Ark, B., \& O'Mahony, M. (2016). Productivity growth in Europe before and since the 2008/ 2009 economic and financial crisis. In D. Jorgensen, K. Fukao, \& M. Timmer (Eds.), The world economy: Growth stagnation (pp. 111-152). Cambridge University Press.

Van Ark, B., \& Jäger, K. (2017). Recent trends in Europe's output and productivity growth performance at the sector level, 2002-2015. International Productivity Monitor, 33, 8-23. 
Open Access This chapter is licensed under the terms of the Creative Commons AttributionNonCommercial-NoDerivatives 4.0 International License (http://creativecommons.org/licenses/bync-nd/4.0/), which permits any noncommercial use, sharing, distribution and reproduction in any medium or format, as long as you give appropriate credit to the original author(s) and the source, provide a link to the Creative Commons license and indicate if you modified the licensed material. You do not have permission under this license to share adapted material derived from this chapter or parts of it.

The images or other third party material in this chapter are included in the chapter's Creative Commons license, unless indicated otherwise in a credit line to the material. If material is not included in the chapter's Creative Commons license and your intended use is not permitted by statutory regulation or exceeds the permitted use, you will need to obtain permission directly from the copyright holder. 